скомпрометировавший себя сотрудничеством с германскими властями атаман генерал П.Н. Краснов.

Подводя краткие итоги, следует отметить, что северокавказский театр Гражданской войны и интервенции во второй половине 1918 г. был крайне пестрым. На Северном Кавказе первоначально почти полностью большевизированный регион в ходе длительных ожесточенных боев постепенно почти полностью (кроме Дагестана) к началу 1919 г. оказывается во власти Добровольческой армии (Вооруженных сил на юге России) [4, с. 60]. Падение Советской власти в регион было обусловлено наличием серьезного врага в лице Добровольческой армии, оторванностью от центральной России и начавшейся борьбой между военным и политическим руководством Северо-Кавказской Советской Социалистической Республики.

1. Добрякова Н.А., Лобанов В.Б. Узун-Хаджи Салтинский - военный и политический деятель периода Революции и Гражданской войны на Северном Кавказе (1917-1920) // Современная научная мысль. 2021. № 2. C. $132-135$.

2. Лобанов В.Б. Административно-территориальное деление Терека и Дагестана в период Революции и Гражданской войны, 1917-1920 гг. // Кавказология. 2021. № 1. С. 67-80.

3. Пученков А.С. Размышляя о Гражданской войне // Вестник Северного (Арктического) федерального университета. Серия: Гуманитарные и социальные науки. 2020. № 4. С. 33-37.

4. Пученков А.С. Южнорусское белое движение и Польша в годы Гражданской войны (1919-1920 гг.) // Вопросы истории. 2020. № 3. С. 53-66.

5. Пыльцын Ю.С., Лобанов В.Б. Терское восстание 1918 г. - стихийное выступление или спланированная операция? // Петербургский исторический журнал. 2020. № 2(26). С. 285-293.

\title{
Камбиев А.М. \\ Терек и Дагестан под властью Терско-Дагестанского края ВСЮР (начало 1919 - март 1920 гг.)
}

Санкт-Петербургский государственный университет аэрокосмического приборостроения doi: 10.18411/trnio-12-2021-125

(Россия, Санкт-Петербург)

\section{Аннотация}

В статье рассматривается проблематика, связанная с периодом Гражданской войны и интервенции на Северном Кавказе в 1919 - начале 1920 г. Характеризуется политика Добровольческой армии (Вооруженных сил на юге России) по отношению к горским деятелям, британцам. Делается акцент на борьбе с горским восстанием во второй половине 1919 - начале 1920 гг. Рассматривается военно-политическая обстановка в кавказском регионе в указанный период, причины, по которым большевикам удалось сравнительно безболезненно овладеть им. Делаются выводы по итогам советизации Северного Кавказа в начале 1920 г.

Ключевые слова: Северный Кавказ, Гражданская война, интервенция, белогвардейцы, британцы, горские повстанцы.

\section{Abstract}

The article deals with the problems associated with the period of the Civil War and intervention in the North Caucasus in 1919 - early 1920. The policy of the Volunteer Army (Armed Forces in the south of Russia) in relation to mountain leaders, the British. Emphasis is placed on the fight against the mountain uprising in the second half of 1919 - early 1920 . The article examines the military-political situation in the Caucasus region during this period, the reasons why the Bolsheviks managed to take it relatively painlessly. Conclusions are drawn based on the results of the Sovietization of the North Caucasus in early 1920. rebels.

Keywords: North Caucasus, Civil War, intervention, White Guards, British, mountain 
Начало 1919 г. было ознаменовано победоносным наступлением Добровольческой армии, преобразованной в Вооруженные силы на юге России, на Северном Кавказе. В январе-феврале 1919 г. была разгромлена XI-ой Красная армия на Тереке, Советская власть в регионе была свергнута [3, с. 61]. Остатки большевистских сил частично отошли на Астрахань, частично ушли в горы Ингушетии и Чечни, часть была интернирована в Грузии. На Тереке была установлена военная диктатура ВСЮР, был образован отдельный регион Терско-Дагестанский край ВСЮР, во главе которого стал генерал В.П. Ляхов (до апреля 1919 г.) [2, с. 47]. Каждый народ Терека получил внутреннюю автономию во главе с местным правителем и национальным советом. В качестве жеста лояльности каждый народ региона должен был выставить в Белую армию дивизию, что встретило неоднозначную реакцию местных народов. Нарушался многолетний негласный договор, по которому местный мусульманские народы выставляли части, набранные из добровольцев на время внешней войны. Также горцы опасались возврата «старого режима», который в данном случае заключался в якобы казачьем управлении всем Тереком [5, с. 285].

В свою очередь терское казачество в массе своей с облегчением встретило приход белогвардейцев на Терек. Совсем недавно было разгромлено Терское восстание июня-ноября 1918 г., часть казаков ушла на соединение с Добровольческой армией, часть отошла в Дагестан, на территорию, подконтрольную Горской республике, и заключила в декабре 1918 г. военно-политический союз, направленный против большевистского тогда Терека. Терское казачье правительство во главе с выбранным атаманом Г.А. Вдовенко провело массовую мобилизацию в Белую армию, началась подготовка по включению народов Терека в состав казачьего войска. Был заключен договор о слиянии ногайцев с казачеством, шли успешные переговоры с осетинами и кабардинцами, которые были прерваны изменившейся военнополитической ситуацией на рубеже 1919-1920 гг.

На рубеже 1918-1919 гг. у белого командования разгорелся очередной конфликт теперь уже с руководством Горской республики. И белогвардейцы, и горские деятели претендовали на одну и ту же территорию - Северный Кавказ. Конфликт «курировался» британцами, пытавшимися играть роль «третейского судьи». Каждая из сторон противостояния считала, что «союзники» стоят за их оппонентами, не понимая, что те преследуют только свои собственные, прежде всего экономические, интересы. Противоборство проходило в форме переговоров и политических перепалок, не переходя открыто в вооруженное русло. Белогвардейцы решили разрешить конфликт, проведя молниеносную военную операцию. Видимо, имелось понимание того, что против них Горская республика не сможет выставить достойного отпора, да и британцы не станут помогать своим незадачливым новоявленным горским подопечным. В мае 1919 г. белые части в ходе кратковременно наступления заняли без боя все крупные центры Дагестана, тем самым включив его в состав Терско-Дагестанского края ВСЮР, которым к тому времени уже командовал генерал И.Г. Эрдели. Во главе нового белого Дагестана был поставлен генерал М. Халилов, бывший до недавнего времени одним и лидеров Горской республики.

Отвоевав в первой половине 1919 г. терское и дагестанское побережье Каспийского моря, белое командование приняло решение о создании собственных военно-морских сил на Каспии [1, с. 87]. К этому моменту здесь существовало еще две морские силы - красная флотилия, базирующаяся на Астрахани, и британская, находившаяся в Порт-Петровске. Поначалу британцы скептически отнеслись к Каспийской военной флотилии ВСЮР, однако постепенно стали передавать белогвардейцам корабли, пока летом 1919 г., в связи с решением полностью покинуть кавказский регион, передали все имевшиеся в их распоряжении корабли под командование каперанга А.И. Сергеева. Флотилия на протяжении второй половины 1919 г. выполняла вспомогательные функции: помогала сухопутным частям в ходе наступления на красную Астрахань и в ходе подавления горского восстания в Дагестане.

Во второй половине 1919 - начале 1920 гг. в горских районах Терека и Дагестана полыхало восстание против белой власти. На Тереке его возглавил аварский шейх Узун- 
Хаджи, создавший по благословению турок Северо-Кавказский эмират и сделавший Ведено своей столицей. Шейх Али-Хаджи Акушинский возглавил восстание в Дагестан. Известный и влиятельный на Северном Кавказе религиозный деятель $H$. Гоцинский занял проденикинскую позицию. Восстание было поддержано горскими деятелями в эмиграции, турками, грузинами, азербайджанцами и большевиками. Для общего руководства восстанием в Дагестане в сентябре 1919 г. был создан Совет обороны Северного Кавказа и Дагестана первоначально во главе с Али-Хаджи Акушинским. Позже власть в этом новом подпольном региональном органе власти перехватили большевики.

На рубеже 1919-1920 гг. ВСЮР находились на грани полного поражения [4, с. 57]. В ходе Северокавказской наступательной операции Кавказского фронта РККА XI-ая Красная армия вступила на территорию Терско-Дагестанского края ВСЮР. Силы края, дислоцированные на Тереке, которые возглавлял генерал И.Г. Эрдели, были сведены во Владикавказский отряд, отступили на территорию Грузии и там были интернированы, несмотря на предварительную договоренность пропустить белые силы через свою территорию. Силы, располагавшиеся в Дагестане, частично сдались красным, частично ушли в горы. Каспийская военная флотилия ВСЮР в марте 1920 г. отошла из Порт-Петровска в персидский порт Энзели, где была интернирована уже британцами.

Подводя краткие итоги, стоит отметить, что Гражданская война и интервенция на Северном Кавказе в 1919 - первой половине 1920 гг. была характерна чередой ярких событий. На Северном Кавказе к началу 1919 г. обстановку в общем и целом контролировали Вооруженные силы на юге России. Им пришлось после разгрома большевиков в начале года столкнуться с противодействием горских деятелей, британских союзников-интервентов, горским восстанием, поддержанным Грузией, Азербайджаном и турками. Возвращение большевиков на Северный Кавказ в 1920 г. решил старые проблемы и создал предпосылки для возникновения новых [3, с. 35].

1. Абдуллаев Я.С., Лобанов В.Б., Михайлов В.В. Азербайджанская Демократическая Республика в борьбе за сохранение территориальной целостности в 1918-1920 гг. // Современная научная мысль. 2018. № 6. С. 81 88.

2. Артемьев А.С., Лобанов В.Б. Добровольческая армия в Терской области: Конец 1918 - первая половина 1919 гг. // Современная научная мысль. 2019. № 1. С. 43-50.

3. Пученков А.С. Размышляя о Гражданской войне // Вестник Северного (Арктического) федерального университета. Серия: Гуманитарные и социальные науки. 2020. № 4. С. 33-37.

4. Пученков А.С. Южнорусское белое движение и Польша в годы Гражданской войны (1919-1920 гг.) // Вопросы истории. 2020. № 3. С. 53-66.

5. Пыльцын Ю.С., Лобанов В.Б. Терское восстание 1918 г. - стихийное выступление или спланированная операция? // Петербургский исторический журнал. 2020. № 2(26). С. 285-293.

\section{Лебедева Л.В. \\ Давыдова С.А. - исследователь кустарной промышленности Пензенской губернии конца XIX века}

Пензенский государственный технологический университет

(Россия, Пенза)

doi: 10.18411/trnio-12-2021-126

\section{Аннотация}

В статье анализируется исследование кустарной промышленности Пензенской губернии 1880-х гг., проведенное С.А. Давыдовой. Рассматриваются перспективы развития кустарных промыслов в губернии и состояние ремесленного обучения в сельских училищах.

Ключевые слова: С.А. Давыдова, кустарные промыслы, ремесленное обучение, Пензенская губерния. 